parallax, 2008, vol. 14, no. 4, 42-54

\title{
The Omnipresent Eye of the Judge - Juridical Evidence in Albrecht Dürer and Lucas Cranach the Elder ${ }^{1}$
}

\author{
Claudia Blümle
}

In English, the term evidence stands for the proof to be brought forward in a court of law. Such linguistic custom already indicates the extent to which juridical practice has been and continues to be determined by a rhetoric of seeing. ${ }^{2}$ In the correlation of speaking and seeing, the court becomes distinguishable as a theatrical space in which the evidence is referred to the vanishing point of an immediate visibility thereby turning the courtroom into a stage for the establishment of the truth to take place under the eye of the judge. The following discussion is concerned with the historical beginnings of this constellation in the fifteenth century, intending to show, by the examples of Albrecht Dürer's engraving Sol Iustitiae and Lucas Cranach the Elder's painting The Judgement of Solomon, the significant contribution of images to the development of this space of juridical visibility.

\section{I}

Erwin Panofsky considers the copper engraving Sol Iustitiae (Christ as the 'Sun of Righteousness'), dated around 1498/99, a work of art 'which in spite of its small size $(79 \times 107 \mathrm{~mm})$ belongs to Dürer's most impressive creations ${ }^{3}$ (Figure 1). The engraving shows a fierce looking lion with a wide-eyed male figure sitting on its back. A mask of flames protruding from the flesh frames the black points of the figure's pupils and the circular eyes whose radiance is being reinforced by a corona and a double halo. With the mask made up of three tongues of flame and oddly grown together with the nose and the eyes drafted in just a few lines, the engraving illustrates the topic of looking which moreover consists in the direct confrontation of the viewer with the fierce look of the lion. Since the sitting figure's head is turned to the right, the direction of its gaze seems to be focussed on a point outside of the picture. Within the male figure, which takes up almost the entire picture frame, a centred verticality is created starting at the top of the foot and the blade of grass and continuing from the tail of the stole to the radiating head, thus dividing the picture in two and conveying to the composition the aspect of equilibrium and disequilibrium. The semicircular, richly draped stole underlines the slight diagonal of the arm's movement and the disequilibrium it creates between the sword pointing straight up in a parallel to the picture margin and the empty pair of scales with its front pan inclined downwards. The topic of the delivery of judgement, which in connection with the topic of seeing uncannily manifests itself in the depiction of the animal and 




Figure 1. Albrecht Dürer, Sol Justitiae, 1498/99. Etching. $7.9 \times 10.7 \mathrm{~cm}$. The Metropolitan Museum, New York.

the flame mask, is related to an exceedingly complex iconography displaying paganantique, astrological, Christian and juridical elements.

It is Erwin Panofsky's merit to have decoded the allegoric pictorial invention 'combining Christian and pagan-antique ideas, planetary god and the Christian notion of God'. Dürer's direct source of inspiration is believed to have been the Repertorium morale written by the Benedictine Petrus Berchorius. ${ }^{5}$ The correlation Sol-Christus is already evident in Johannes Virdung's woodcarving for the Latin Almanac of the year 1495 (Figure 2). In Virdung's depiction, however, the two figures are standing next to each other, while in Dürer's engraving they are one superimposed on the other and thereby unified in one figure. Roman coins are considered to have served as the antecedents of the pictorial relationship Sol-Christus: on them the respective Emperor - prominent examples are 


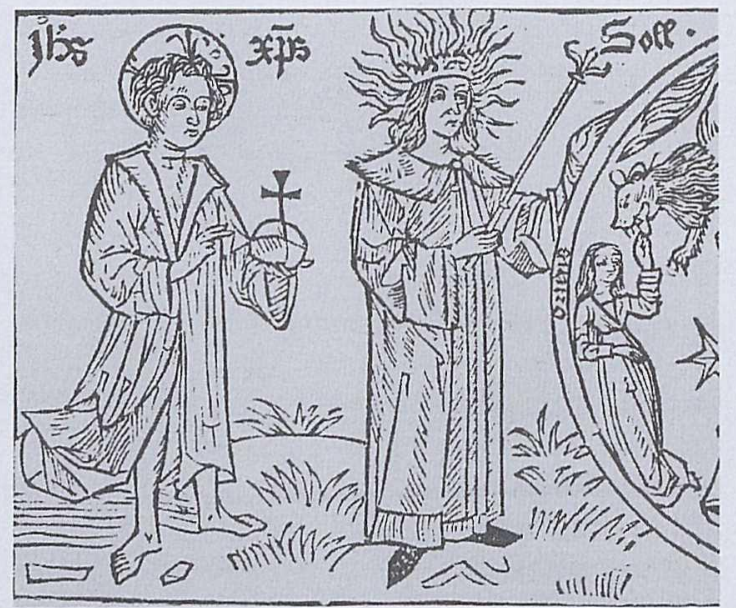

Figure 2. Johannes Virdung, 'Christ and Sol', Almanach for the Year 1495 (detail). Woodcut. Picture 98 in Friedrich Teja Bach, Struktur und Erscheinung: Untersuchungen zu Dürers graphischer Kunst (Berlin: Gebrüder Mann, 1996), p.106.

Probus, Aurelius and Constantine - is shown in profile next to the haloed Sun God and endowed with a facial resemblance to the divine prototype (Figure 3). Ernst Kantorowicz demonstrated by way of the phenomenon of dual images that it was only thanks to this pictorial effectiveness of geminatio, a 'duplication' in the sense of Kantorowicz, ${ }^{6}$ that the Emperor could become geminata persona - 'human by nature and divine by grace'.

In Christian hermeneutics, the geminatio explained by example of the Roman coins of the third and fourth century, is typologically turned around. According to Friedrich Ohly, ${ }^{8}$ typology, although anchored in the exegesis of the Scripture, refers in its interpretative mode of thought also to extra-biblical objects from antique philosophy, lyrics or historical secular stories. As a Christian doctrine which in so doing nonetheless

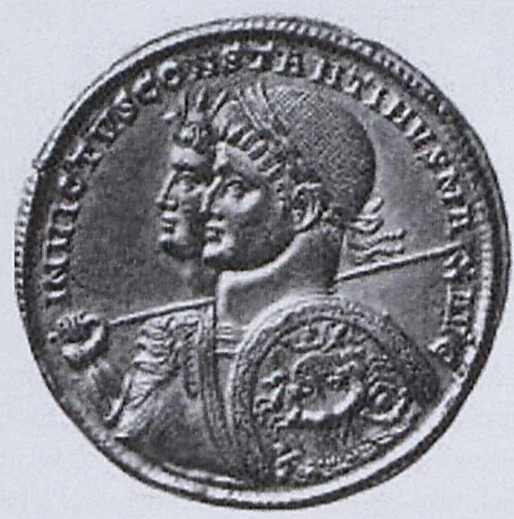

Figure 3. Konstantin and Sol invictus, Gold-Solidus. Bibliothèque Nationale, Paris. Picture $32 \mathrm{e}$ from Ernst Kantorowicz, Die zwei Körper des Königs: Eine Studie zur politischen Theologie des Mittelalters (Stuttgart: Klett-Cotta, 1992 no. 332e). contributed to an antique tradition, typology allegorizes not only Prometheus, Plato and other figures, but moreover, regards them as prefigurations of Christ. ${ }^{9}$ In the fine arts this mode of thought manifests itself as a system of similarities. 'An approximation of the two sides by assimilations raising the common aspects beyond the discontinuities and leading to an interpenetration of type and antitype $^{, 10}$ is so common in the fine arts 'that in appearance type and antitype are all but synthesized'. ${ }^{11}$ This phenomenon is illustrated by a series of well-known paintings and drawings by Leonardo da Vinci combining the aspects of John the Baptist and Bacchus. While the painting of 1509 in the Louvre clearly shows John 
the Baptist, the male figure in the drawing John-Bacchus of 1513 with its antiquating nakedness and the tree tops veiling its face, includes elements of a Bacchus that were to emerge even more dominantly in the painting of 1513-15. Here, the figure wears a leopard hide and a wine leaf corona in its hair while the sign of the cross has disappeared from the staff. ${ }^{12}$ Leonardo da Vinci presents an antique and a biblical type 'synthesized in a way that before the non-spiritual eye they conceal themselves one in the other'. ${ }^{13}$ Ohly describes the correlation of old and new, of extra-biblical and biblical as 'Ineinanderschau'. ${ }^{14}$ This 'looking of one into the other' is possible not only iconographically because of interpretable attributes, characteristics and symbols but also because of the picture's specific effectiveness which rests upon the simultaneous perception of elements the mind reads either separately or linearly. Referring to Lucan, Panofsky calls such a synthesis a numen mixtum, a mixed divinity synthesized from two opposing divinities. ${ }^{15}$

Within the framework of this interpretation of Sol-Christus the scale presents a problem from an iconographic point of view given that Christ as Judge of the World had always been depicted with a white lily and a sword. Dürer's portrayals of the Last Fudgement incorporate these Christian attributes taken from the Gospel of St. John while scale and sword are ascribed to the Arch Angel Michael or the female personification of Fustitia. ${ }^{16}$. Hence, the question is whether the engraving Sol Iustitiae represents a numen mixtum or an allegory. Does the picture communicate the delivery of judgement as an abstract idea or as a salvation-historical event? Kurt Rathe underlined in 1927 that Dürer succeeded in synthesizing 'the late medieval and antique perception of justice in a dreadful pictorial face of his very own quality'. ${ }^{17}$ Thomas Würtenberger also placed the engraving Sol Iustitiae within the more comprehensive legal context of Dürer's work corpus. ${ }^{18}$ Within the Sol-Christus typology the juridical aspect is relevant insofar as it is not the attributes but rather the reference to the judicial posture allowing for the figure to be interpreted as Christian Judge of the World. Since, however, the picture presents both a coincidence of antique, astrological, Christian and allegoric iconography as well as a synopsis of all these different aspects in one single figure, it is impossible to determine the dominating aspect. In the case of da Vinci's Bacchus-Fohn the Baptist series, the two deities can still be clearly distinguished thus allowing for an interpretation from a salvation-historical point of view and to read Bacchus as the prefiguration of John. The moment, however, attributes of an abstract prefiguration are introduced, the problem becomes more complex. For, it is the scale and sword which bestow upon 'the picture the allegory's higher degree of abstraction'. ${ }^{19}$ Besides the ideal personification of justice, the iconographic variant of Sol Iustitiae becomes even more complicated because of its references to the judicial civil servant activity.

Judges in the Middle Ages were still dispensed of having to make their own decision as is well documented by Susanne Lepsius. 'According to the belief at the time, the "truth of the matter" immediately revealed itself by divine intervention in the ordeal and the oath taking,. ${ }^{20}$ On the metaphysical assumption that God would decide legal matters by performing a miracle, it was possible 'from the point of view of the members of court partaking in the trial to establish complete knowledge of the facts and administer 
justice'. ${ }^{21}$ Given this trial by ordeal, it is therefore not possible to speak of a judge in the modern sense but merely of a referee whose task it was to observe compliance with the rules during the dispute, the oath taking and the ordeal. Upon rediscovery and the new translation of Roman Law in the late Middle Ages, the judges and the judgement passing power were all of a sudden confronted with the problem of having to deliver judgement themselves. In Sol Iustitiae the newly emerging judicial task is combined not only with the allegoric attributes of justice (sword and scale) but also with the astrological iconography of Sol:

From time immemorial, Sol as the planetary god had also always been associated with the function of the judge. Vettius Valens for instance introduces him as the trustee of judgement, a characterisation which ultimately goes back to the Babylonian Sun God. ${ }^{22}$

This new focus on the judge in penal court proceedings is depicted and reflected in The Judgement of Solomon by Lucas Cranach the Elder and his studio (Figures 5 and 6). ${ }^{23}$ In the painting which is dated around 1537 and displays several similarities with Dürer's Sol Iustitiae, King Solomon is also surrounded by four fierce looking lions. Here, the lion refers first of all to a juridical iconography. Vital Huhn showed that 'already in early Christian times and particularly in Italy, the lion as an emblem of the court had evolved from antique oriental perceptions of power' ${ }^{24}$ Since the times of Carolingian Rule it stood for high justice (also known as the blood court). ${ }^{25}$ The columns from which death sentences were proclaimed were borne by four crouching lions and called 'Tattermannsäulen' in Bamberg because their sight made people 'dattrig', i.e. tremble with fear. ${ }^{26}$ And in the words of the Town Charter of Soest the judge was 'to exercise his office as a grim faced lion'. ${ }^{27}$

Besides the lion's iconographic reference to the law, the posture - albeit mirrored corresponds exactly to the one in Sol Iustitiae (Figures 4 and 5). King Solomon not only crosses his legs in a judicial manner, his head is equally inclined to the side. When looking at the painting as a whole, the royal judge's throne is elevated to the image's vanishing point and thus positioned in a way that in order to be able to see the scene in the foreground his head has to turn to the left (Figure 6). There, two female figures are composed in opposition to one another: while the one with the dead child is kneeling, the other is standing with a living child in her arms. Positioned between them is a henchman reaching out for the living child while drawing his sword to cut the child in two. Cranach's painting relates the story of King Solomon as told in the Old Testament's first Book of Kings whereupon he has to pronounce judgement after having heard two different testimonies. He is confronted with two mothers who had given birth the same night; when one of the infants died the two women turned to the judge each of them claiming that the living child was theirs. The King then ordered a sword brought to him and he ruled: 'Divide the living child in two, and give half to the one, and half to the other. ${ }^{28}$ When one of the two women pleaded with him not to kill the child while the other wanted the child neither to belong to her nor to the other, the King was able to determine that the former was the real mother and all Israel saw 'that the wisdom of God was in him, to do judgement'. ${ }^{29}$ In the painting by Cranach and his studio, this structure becomes particularly apparent in the architecture and because of the different observer positions. The exemplary case takes place in a theatrical court 
room under the eyes of Solomon while the audience observes the two women's dispute from a gallery further up. The remarkable symmetry of the painting culminates in the figure of the royal judge moved to the background and sitting on a throne decorated with two white columns. The steep central perspective construction of the stage is reinforced by the black draped curtains and the stone benches to the left and to the right of the throne. Within this self-contained space the judicial gaze takes a backseat while the scene comes to the fore of the painting as a place of pure visibility. This architecturally induced viewing constellation displays a remarkable affinity to the one common in Renaissance theatre which according to Hans-Christian von Hermann produces a scene by means of perspective, curtains and lighting effects thus explicitly illustrating 'the unity of drama formulated by Aristotle as the unity of one single scene (Schauplatz) constituted by "one" single gaze'. 30 The scene constituted by 'one' single gaze perspectivizes the event to one single position which on stage is taken by the king and in the court room by the judge as the singled out viewer and observer. In the painting by Cranach the grey gallery wall and the king's separation from the audience on the gallery in the back underline the singling out on stage of one single eye point the more so as this sovereign eye point coincides with the perspective vanishing point.

Cranach's painting illustrates how the court is transformed to become a stage. Like the circular arrangements in medieval theatre, ordeals, disputes or oath takings had no stage in the sense that a self-contained space could be observed from one single sovereign eye point. Instead, the audience arranged in a circle was able to watch the legal plays from different positions and observe compliance with the rules along with the judge. The moment, however, judgement is no longer delivered by God but by the judge, court proceedings require a central scenic place in the courtroom within which the event is to unfold. The scene becomes the new show-place of a no longer theological truth. The

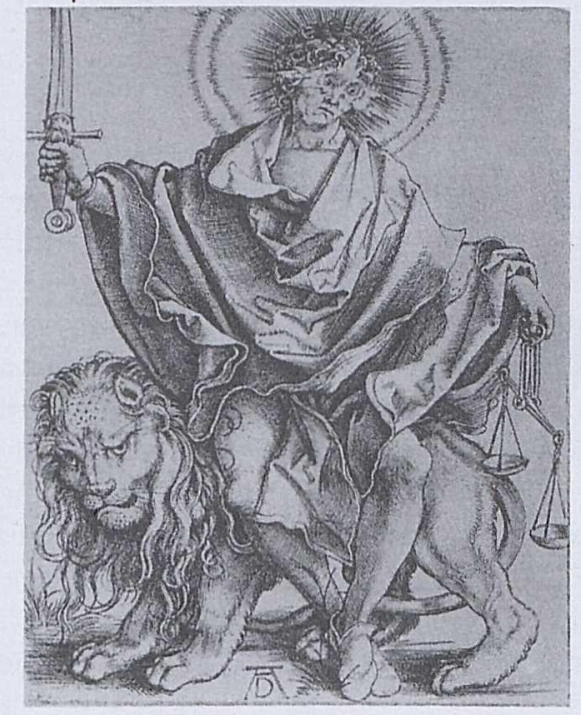

Figure 4. Albrecht Dürer, Sol Justitiae, 1498/99. Etching. $7.9 \times 10.7 \mathrm{~cm}$. The Metropolitan Museum, New York. audience is henceforth positioned behind the sovereign judicial eye in order to partake in it. From a law historical point of view Cranach's theatrical depiction of the King's Hall as the place of high justice continues an antique tradition since prior to the division of the ancient round and self-contained arena into a stage as scene, antique drama and jurisdiction were directly correlated. ${ }^{31}$ Upon rediscovery of the antique theatre in the Renaissance, the court again becomes a theatre by way of the scene. Here, as is shown in Cranach's painting, the crucial factor is the architectural partition in actors and audience, in active and passive participants, in those moving and those watching. For, the issue the judges were confronted with at the time, i.e. of having to come to a decision and a judgement, is tied to this theatrical distinction: 'Those watching can also decide. Stepping back, seeing and gaining 


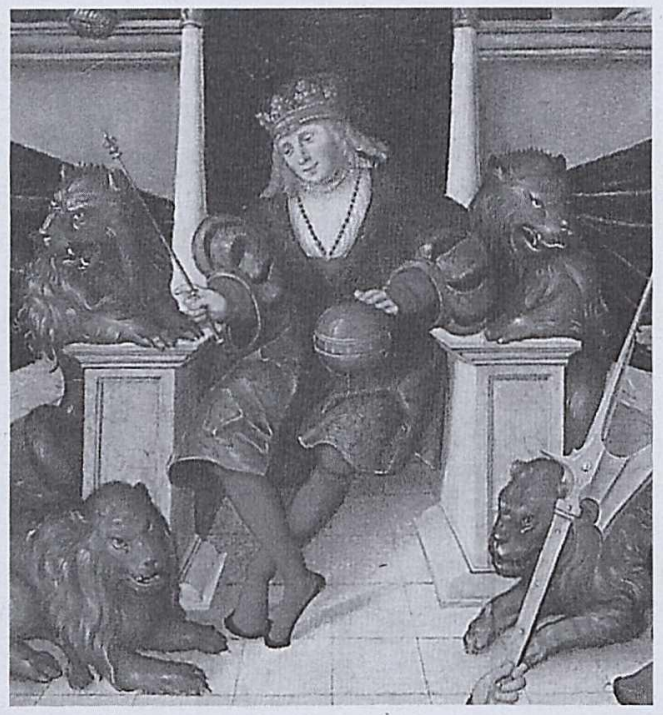

Figure 5. Lucas Cranach the Elder and workshop, The Judgement of Solomon (detail), 1537. Oil on poplar. $206.5 \times 142 \mathrm{~cm}$. Staatliche Museen zu Berlin, Preußischer Kulturbesitz, Gemäldegalerie, II.76. Photo: Jörg P. Anders.

insight, gaining insight and deciding form an interlinked series at the end of which would be the independent reflexive decision'. ${ }^{32}$ It was not until the late Middle Ages that the judicial gaze became the decisive factor for the judicial establishment of the truth. Since the judge now passes judgement in God's stead, he must take on a corresponding divine gaze in order to occupy the place of an absolute truth.

In Cranach's painting, the judge's gaze and the people observing from the gallery constitute precisely those observer positions that transfer the entire picture to a 'stage on the stage' (Figure 6). While the scene as a place of pure visibility is moved to the foreground, the gaze of the judge positioned in the vanishing point of the central perspective construction establishes the image's centre. His gaze does not, however, end in the vanishing point but constitutes at the same time the starting point of the scene. Unless the judge oversees the scene in the courtroom, the audience - as depicted behind the tribune - will not be able to partake in the unfolding of the truth. Any unfolding of the truth can only take place the moment the judge as the sovereign of the juridical stage warrants the context of the event on stage and looks at it from his elevated viewing position; only then will the audience as depicted on the tribune be able to partake in the event. Without the judicial eye taking in the scene and without it being omnipresent at all times during the trial, the court cannot be a place for the establishment of the truth.

Dürer's Sol Iustitiae transfers these very conditions of juridical evidence to a picture by providing the male judge figure endowed with the attributes of justice and sitting on a 


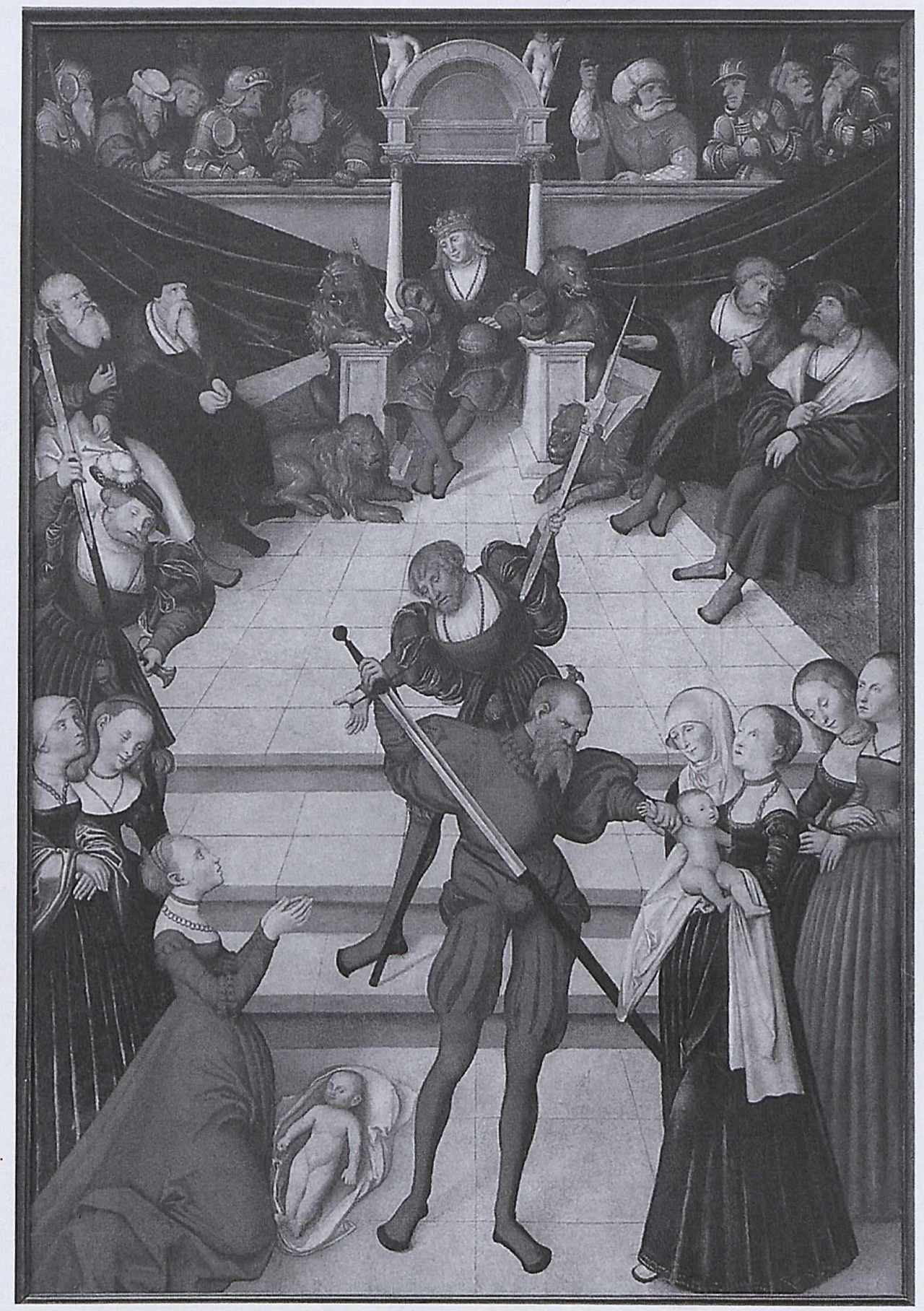

Figure 6. Lucas Cranach the Elder and workshop, The Judgement of Solomon, 1537. Oil on poplar. $206.5 \times 142 \mathrm{~cm}$. Staatliche Museen zu Berlin, Preußischer Kulturbesitz, Gemäldegalerie, II.76. Photo: Jörg P. Anders. 
lion with the glow of a halo. Iconographically, Christ is depicted with a cross nimbus and Sol with a flaming corona and an aureole. In the ancient sun cult the Sun God called Helios by the Greek and Sol by the Romans and commonly portrayed on coins, grave stones or in temples - was characterized by a halo of rays of light. This halo could take on two geometrically different forms: it could be a nimbus in the form of a round disc or circle or a corona 'in the form of rays radiating from the head' ${ }^{33}$ The nimbus which in reference to the sun had originally been reserved for the solar deity of light was soon transferred to demigods, heroes or personifications whereas the corona modelled on the sun came to prevail in the depiction of rulers. In Dürer's engraving the two types are unified: the hatched corona is framed by a circular nimbus which is drawn in small parallel lines and doubled. As a result of the gradual tradition of the Sun God's nimbus and corona to Christian use, a clear distinction between Sol and Christ with regard to the halo is not possible. In Dürer's depiction the brilliance of the fiery solar deity whose solar connotation was eventually displaced 'in favour of a more comprehensive character of light ${ }^{34}$ and transferred onto Christ, now becomes thematic in connection with seeing by linking the blazing flame mask of his Sol Iustitiae to the wide open eyes. Panofsky noticed that a similar mask appears on the first sheet of Dürer's series on the Apocalypse of St. Fohn ${ }^{35}$ titled Vision of the Seven Candlesticks (Figure 7):

But the face of the man is surrounded with a quivering halo, his eyes burst into flames like those of the Son of Man in the Vision of the Seven Candlesticks, and his features show a fierce, yet woeful expression, strangely akin to that of his fantastic mount. ${ }^{36}$

The argument that Sol Iustitiae represents Christ the Judge of the World gains in persuasiveness when compared to the woodcarving from the Apocalypse of the same year. In both sheets the flaming rays merge with the curly hair and the lines of the corona. In the case of Christ, the mask consisting of two parts and thus leaving the frowned front visible, appears like a prolongation of the brows and the eye lashes with the two flames adapting to the almond-shaped eyes (Figure 7), while the dominating forms in Sol Iustitiae are circular and cross-shaped (Figure 8). The circular lines bring

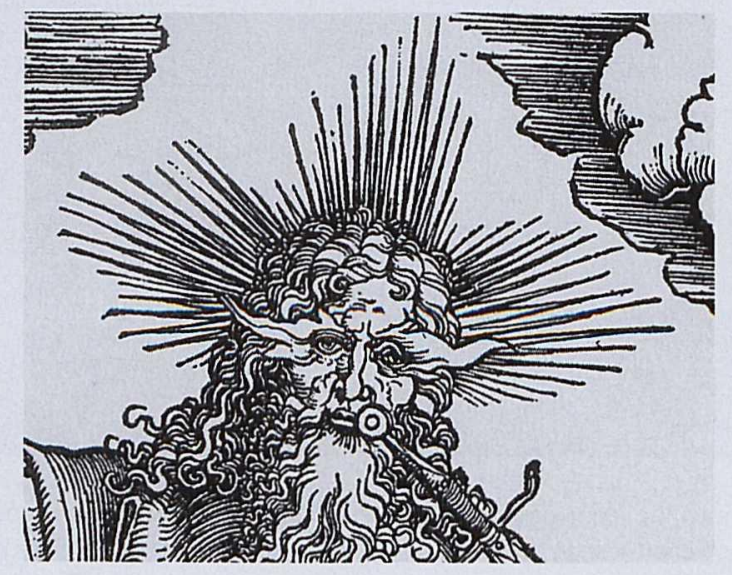

Figure 7. Albrecht Dürer, 'The Vision of the Seven Candlesticks' from the first folio in The Apocalypse, 1498. Woodcut. $39.2 \times 28.1 \mathrm{~cm}$. 
forth the black pupils, the shape of the eyes, the eyelids and the formation of the flames inside the mask thereby accommodating the circular eyes, whereas the tongues of the flames pointing in three directions result in a cross similar in depiction to the cross nimbus in Virdung's woodcarving (see Figures 2 and 7).

Nikolaus von Kues ascribes the significance of the divine gaze from the picture as depicted by Dürer to its particularity and concurrent omnipresence. ${ }^{37}$ According to Jacques Lacan, the function of the icon is also to be seen in the fact that 'also the God it depicts gazes at it'. ${ }^{38}$ In Dürer, the resulting omnipresent gaze of God is moreover tied to a mask so that in this depiction of the judge of the world the pictorial characteristics of the gaze of the all seeing God are further reinforced. Unlike the divine gaze in the apocalyptic woodcarving Vision of the Seven Candlesticks, the gaze in Sol Iustitiae is not on the viewer of the picture but stays within the space of the picture and is focussed on the lower right-hand corner. This focus on one particular point is of relevance as it prevents the prominence of a gaze capable of incarnating God's particular as well as omnipresent eye. Instead, because of the inclination of the head and the direction of the gaze towards one particular point, the position of the judge corresponds exactly to the one in Cranach's painting. Dürer's pictorial invention is distinct from the depiction of the divine Judge of the World by passing - in Jacques Lacan's words - from the gaze to the eye: The moment the gaze of the judge is lowered and thus becomes the eye, the court room shifts to a room of visibility. The eye believing to be ruling the events on stage by means of the eye point as in the central perspective construction, decorates itself with the gaze which in combination with the light in the depictions of the Christian God and of the antique Sol/Helios shows itself as more omnipresent.

In Sol Iustitiae the viewer is at eye level with the stooped lion whose head is slightly raised. Thus the impression is created that the male figure takes an elevated observer position and could thereby be looking down on the viewer. This low horizontal line is reinforced by the haloed man wearing the fire mask whose chin is depicted from below. In Cranach's painting the steep perspective construction of the room and Solomon's position in the image's upper fifth also create an emphasis of the extremely high angle.

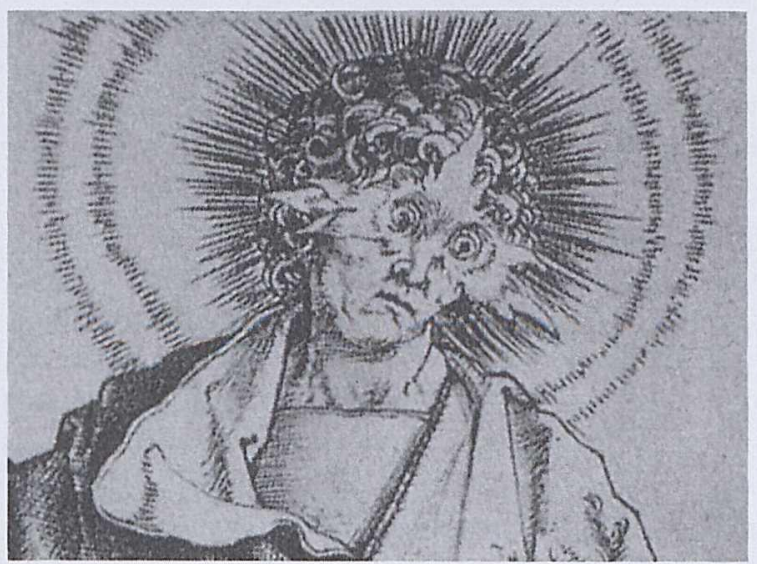

Figure 8. Albrecht Dürer, Sol Justitiae (detail), 1498/99. Etching. $7.9 \times 10.7 \mathrm{~cm}$. The Metropolitan Museum, New York. 
The elevated observer position is explained by the older practice of jurisprudence for which such a position was indispensable; this is illustrated by the word Lê or Lee which in Middle High German named the hill of jurisdiction. For, in high justice the elevated place of the scaffold served the purpose of 'better visibility' ${ }^{39}$ Moreover, since the common use of the word Lee was frequently mistaken with the similar sounding word Lêtee (lion) the animal came to symbolize high justice. In summary it may therefore be said that not only the posture with the crossed legs but also the elevated observer position, as well as the focussing of the eyes on one particular point, are related to a judicial context thus bearing no relationship to either a Christian or allegorical context. The judicial view allowing for an overview of the entire proceedings is at the same time physical and metaphysical because it always also takes the place of the divine gaze. Dürer uses the halo to transcend this seeing which constitutes the starting point of the juridical unfolding of the truth and must from now on assume the newly emerging activity of weighing and judging.

Kantorowicz was able to show by way of the nimbus how the temporal aspect of a continuum could be bestowed on supra-individual ideas: 'In late antique art, we often find the halo bestowed on such figures as might impersonate a supra-individual idea'. This mark of distinction indicated that 'the figure was meant to represent in every respect a continuum, something permanent and sempiternal beyond the contingencies of time and corruption'. ${ }^{40}$ Kantorowicz stresses that female figures mostly denoted as abstractions or personifications, as Roman provinces for instance, thereby received their 'supra-temporal character' within the continuity of time. The same was true 'with regard to notions or virtues: Fustitia or Prudentia, who were goddesses in pagan Antiquity were meant to represent forces perpetually effective'. ${ }^{41}$ This dimension of time leads to the distinction between tempus, aeternitas and aevum, between transient earthly time, apocalyptic eternity and sempiternity. The halo thereby indicates a change in the nature of time; it removes its bearer 'scholastically speaking, from tempus to aevum, from Time to Sempiternity, at any rate to some continuum of time without end'. ${ }^{42}$

\section{IV}

It should be recalled once more that Sol Iustitiae is neither an allegory of Justitia nor about the solar zodiac sign of Leo; it is not about Christ, the apocalyptic Judge of the World, or the antique Sun God Helios/Sol, nor is it about a judge exercising his office. Instead, all of these aspects which also exist in single depictions are found in one picture, united in one haloed figure with flaming eyes. All of this, however, still leaves the question whether it is an allegory of a secular activity or a divine numen mixtum. This question is of relevance as allegory and numen mixtum involve different time concepts. If Sol Iustitiae is read typologically, i.e. Sol as a prefiguration of Christ, the depiction would relate to a salvation-historical concept of time and thus to a coming eternity relieved of space and time. If, on the other hand, the picture is read as an allegory, it would stand for a sempiternal abstract idea. The effect and power of the picture which rests in the simultaneous synthesis of different elements, concepts and ideas, is epitomized in Sol Iustitiae by being at the same time numen mixtum and allegory. In this cross-fading of numen mixtum and allegory, Sol Iustitiae on the one hand lends an allegorical aspect to the activity of passing judgement by investing it with lion, scale and sword, and on the 
other it applies a continuity to the judicial office by combining the halo with the flame mask and the focussing of the gaze. Apart from the omnipresent eye of the judge in the elevated observer position, the lion as the symbol of alertness is also given an aspect of continuity as his eyes never close, not even in sleep. Sol Iustitiae unites the two concepts in order to typologically change the judicial office and to invest it with an aevum as well as with the power hitherto reserved to the divine. The Apocalypse becomes an innerworldly event and the inner-worldly judicial office enters the realm of the holy (or of the antique Gods, of astrology and the apocalypse). Thus, immanence and transcendence are correlated in a genuinely pictorial way. The judge's view, as is shown in Dürer's Sol Iustitiae, is consequently an undisguised and direct seeing going beyond the mere and contingent presence. As a metaphysical view, it determines instead the stage on which the truth unfolds and thus also the place of the evidence as judicial inspection and as being evident.

\section{Translation: Jacqueline Cisuss}

Notes

1 This text will be also published in German. Claudia Blümle, 'Der allgegenwärtige Blick des Richters: Juridische Evidenz bei Albrecht Dürer und Lucas Cranach d. A', in Movens Bild. Zwischen Evidenz und Affekt, ed. Gottfried Boehm, Birgit Mersmann und Christian Spiess (München: Wilhelm-Fink Verlag, 2008).

${ }^{2}$ See also Piyel Haldar, 'The Evidencer's Eye: Representations of Truth in the Laws of Evidence', Law and Critique, 2:2 (1991), pp.171-89.

${ }^{3}$ Erwin Panofsky, The Life and Art of Albrecht Dürer, 2nd edn (Princeton: Princeton University Press, 1948), p.78.

${ }^{4}$ Reiner Schoch, 'Die Sonne der Gerechtigkeit (Sol Iustitiae)', in Germanisches Nationalmuseum Nümberg, Albrecht Dïrer. Das druckgraphische Werk, Bd. I, ed. Anna Scherbaum (München: Prestel, 2001), pp.7980 (p.79).

${ }^{5}$ Elfriede Scheil, 'Albrecht Dürers Melencolia § I und die Gerechtigkeit', Zeitschrift für Kunstgeschichte, 2 (2007), pp.201-14 (p.203).

${ }^{6}$ Ernst H. Kantorowicz, The King's Two Bodies: A Study in Mediaeval Political Theology (Princeton: Princeton University Press, 1997), p.58.

7 Ernst $\cdot H$. Kantorowicz, The King's Two Bodies: A Study in Mediaeval Political Theology, p.65.

${ }^{8}$ Friedrich Ohly, 'Halbbiblische und außerbiblische Typologie', in Schriften zur mittelalterlichen Bedeutungsforschung (Darmstadt: Wissenschaftliche Buchgesellschaft, 1977), pp.361-400.

9 Friedrich Ohly, 'Halbbiblische und außerbiblische Typologie', p.396.

10 Friedrich Ohly, 'Halbbiblische und außerbiblische Typologie', p.396.
11 Friedrich Ohly, 'Halbbiblische und außerbiblische Typologie', p.396.

12 For a detailed discussion of the pictorial synthesis of John and Bacchus, see Erwin Panofsky, A Mythological Painting by Poussin in the Nationalmuseum Stockholm (Stockholm: Norstedt \& Söner, 1960), pp.36-44, and Friedrich Ohly, Halbbiblische und außerbiblische Typologie, pp.396-400, Figures 27-30.

13 Friedrich Ohly, 'Halbbiblische und außerbiblische Typologie', p.397.

14 Friedrich Ohly, 'Halbbiblische und außerbiblische Typologie', p.397.

${ }^{15}$ Erwin Panofsky, A Mythological Painting by Poussin in the Nationalmuseum Stockholm, p.40.

16 For the iconography of justice see Rudolf Ott Kissel, Die Justitia: Reflexionen über ein Symbol und seine Darstellung in der bildenden Kunst (München: C. H. Beck, 1984).

${ }^{17}$ Kurt Rathe, 'Der Richter auf dem Fabeltier', in Festschrift für Julius Schlosser zum 60. Geburtstage, ed. Arpad Weixlgärtner and Leo Planiscig (Zürich: Amalthea-Verlag, 1927), pp.187-208 (p.188).

18 Thomas Würtenberger, 'Recht und Gerechtigkeit in der Kunst Albrecht Dürers', in Kinst und Recht: Festgabe für Hans Fehr, Bd. 1 (Karlsruhe: Verlag C.F. Müller, 1948), pp.221-35; and Thomas Würtenberger, Albrecht Dürer: Künstler - Recht Gerechtigkeit (Frankfurt: Vittorio Klostermann, 1971).

19 Reiner Schoch, 'Die Sonne der Gerechtigkeit (Sol Iustitiae)', p.80.

${ }^{20}$ Susanne Lepsius, 'Wissen=Entscheiden, Nichtwissen=Nichtentscheiden?: Zum Dilemma richterlicher Beweiserhebung im Spätmittelalter und in der frühen Neuzeit', in Urteilen/Entscheiden, 
ed. Cornelia Vismann and Thomas Weitin (München: Wilhelm Fink-Verlag, 2006), pp.119 42 (p.120).

21 Susanne Lepsius, 'Wissen=Entscheiden, Nichtwissen $=$ Nichtentscheiden?', p.121.

${ }^{22}$ Friedrich Teja Bach, Struktur und Erscheinung. Untersuchungen zu Dürers graphischer Kunst (Berlin: Gebr. Mann Verlag, 1996), p.101.

${ }^{23}$ With regard to the painting see Max J. Friedländer, Jakob Rosenberg, The Paintings of Lucas Cranach, trans. Heinz Norden (Ithaca, NY: Cornell University Press, 1978); Kurt Simon, Abendländische Gerechtigkeitsbilder (Frankfurt: Kramer, 1948), p.60 and p.103, Footnote 96; Rainer Michaelis, Deutsche Gemälde: 14.-18. Jahrhundert (Berlin: Staatliche Museen zu Berlin, 1989), p.25; Henning Bock, Gemäldegalerie Berlin: Gesamtverzeichnis (Berlin: Staatliche Museen zu Berlin, 1996), p.35.

24 Vital Huhn, 'Löwe und Hund als Symbol des Rechts', Mainfränkisches Jahrbuch für Geschichte und Kunst, 7 (1955), pp.1-63 (p.62).

25 Vital Huhn, 'Löwe und Hund als Symbol des Rechts', p.58.

26 Vital Huhn, 'Löwe und Hund als Symbol des Rechts', p.11.

27 Kurt Rathe, 'Der Richter auf dem Fabeltier', p.201, Footnote 32 .

28 Kings 3, 16:28.

29 1 Kings 3, 16:28.

30 Hans-Christian von Herrmann, Das Archiv der Bühne: Eine Archäologie des Theaters und seiner Wissenschaft (München: Wilhelm Fink-Verlag, 2005), p.62.

31 Cornelia Vismann, 'Das Drama des Entscheidens', in Urteilen/Entscheiden, ed. Cornelia Vismann and Thomas Weitin (München: Wilhelm Fink-Verlag, 2006), pp.91-100 (p.98).

32 Cornelia Vismann, 'Das Drama des Entscheidens', p.92.

33 Martin Wallraff, Christus verus sol: Sonnenverehrung und Christentum in der Spätantike (Münster:
Aschendorffsche Verlagsbuchhandlung, 2001), p. 145 .

34 Martin Wallraff, 'Christus verus sol: Sonnenverehrung und Christentum in der Spätantike', p.145.

35 Peter Krüger, Dürers "Apokalypse": Zur poetischen Struktur einer Bilderzählung der Renaissance (Wiesbaden: Harrassowitz Verlag, 1996).

36 Erwin Panofsky, The Life and Art of Albrecht Dürer, p.78.

37 Nicolaus Cusanus, 'Uber das Sehen Gottes (de visione Dei)', in Philosophische und theologische Schriften, übers. von Anton Scharpff und Eberhard Döring (Darmstadt: Wissenschaftliche Buchgesellschaft, 2005), pp.233-82. For the picture theoretical relevance of this text, see Gottfried Boehm, Studien zur Perspektivität: Philosophie und Kunst in der Frühen Neuzeit (Heidelberg: Winter, 1969), pp.137-71; as well as Holger Simon, 'Bildtheoretische Grundlagen des neuzeitlichen Bildes bei Nikolaus von Kues', Concilium medï aevi, 7 (2004), pp.45-76.

38 Jacques Lacan, Die vier Grundbegriffe der Psychoanalyse (Weinheim: Quadriga, 1996), p.120. Michel de Certeau demonstrates structural common grounds between Nikolas von Kues and Lacan. Michel de Certeau and Nikolas von Kues, 'Das Geheimnis eines Blickes', in Bildlichkeit, ed. Volker Bohn (Frankfurt: Suhrkamp, 1990), pp.325-56, in particular pp.34548. See also on the distinction of eye and gaze, Claudia Blümle and Anne von der Heiden, eds, Blickzähmung und Augentäuschung: Zu Jacques Lacans Bildtheorie (Berlin/Zürich: Diaphanes, 2005).

${ }^{39}$ Vital Huhn, 'Löwe und Hund als Symbol des Rechts', p.60.

40 Vital Huhn, 'Löwe und Hund als Symbol des Rechts', p.79.

41 Ernst H. Kantorowicz, The King's Two Bodies: A Study in Mediaeval Political Theology, p.79.

42 Ernst H. Kantorowicz, The King's Two Bodies: A Study in Mediaeval Political Theology, p.84.

Glaudia Blümle studied Art History, German Literature and History in Basel and Berlin. From 2002 through 2005 she was a research fellow at Bauhaus-University Weimar. Since 2005, she teaches Art History at University Basel. Here doctoral thesis about Truth and Juridical Forms in Early Modern Painting will be published in 2009. Among her numerous publications, Claudia Blümle has contributed to Visuelle Argumentation, eds Horst Bredekamp und Pablo Schneider (München: Wilhelm Fink Verlag, 2005) and Bildregime des Rechts, eds Jean-Baptiste Joly, Cornelia Vismann and Thomas Weitin (Stuttgart: Schloss Solitude, 2007). She is also the editor (with Armin Schäfer) of Struktur, Figur, Kontur. Abstraktion in Kunst und Lebenswissenschaften (Berlin/ Zürich: Diaphanes, 2007). 